\title{
Evaluation of the Dietary Intake of Cadmium, Lead and Mercury and Its Relationship with Bone Health among Postmenopausal Women in Spain
}

\author{
Luis M. Puerto-Parejo ${ }^{\dagger}$, Ignacio Aliaga ${ }^{\dagger}$, María L. Canal-Macias, Olga Leal-Hernandez, \\ Raul Roncero-Martín, Sergio Rico-Martín and Jose M. Moran * \\ Metabolic Bone Diseases Research Group, Nursing Department, University of Extremadura, 10003 Caceres, \\ Spain; Impuerto@unex.es (L.M.P.-P.); i.aliaga@pdi.ucm.es (I.A.); luzcanal@unex.es (M.L.C.-M.); \\ olgaleal@unex.es (O.L.-H.); rronmar@unex.es (R.R.-M.); sergiorico@unex.es (S.R.-M.) \\ * Correspondence: jmmorang@unex.es; Tel.: +34-927-257-450 \\ + These two authors contributed equally to this article.
}

Academic Editor: Paul B. Tchounwou

Received: 10 March 2017; Accepted: 20 May 2017; Published: 26 May 2017

\begin{abstract}
Background: Heavy metals, such as lead, cadmium, and mercury, are absorbed through contaminated food sources and water. Few studies have investigated the extent to which dietary heavy metals are associated with low bone mineral density. Aims: We aimed to characterize the dietary intake of the heavy metals lead, cadmium and mercury among healthy, non-smoking postmenopausal women in Spain. Furthermore, we sought to establish a putative relationship between bone health and the intake of these heavy metals in this population. Study Design: The daily intake of the heavy metals considered for the different food groups was calculated by accounting for food content and consumption in 281 postmenopausal women. Bone measurements were performed using a Quantitative Bone Ultrasound (QUS), a Dual-Energy X-ray Absorptiometry (DXA) and a Peripheral Quantitative Computed Tomography (pQCT). Results: The average estimated dietary cadmium exposure among the 281 women studied was $29.87 \mu \mathrm{g} /$ day $(20.41-41.04)$ and $3.03 \mu \mathrm{g} / \mathrm{kg}$ body weight (b.w.; 2.17-4.40). Dietary lead exposure was $46.24 \mu \mathrm{g} /$ day $(38.11-54.77)$ and $4.87 \mu \mathrm{g} / \mathrm{kg}$ b.w. (4.00-6.14). The estimated dietary mercury exposure was $11.64 \mu \mathrm{g} /$ day and $1.19 \mu \mathrm{g} / \mathrm{kg}$ b.w. (0.82-1.76). Participants were classified according to their heavy metal intake (above or below the respective medians). After further adjustment for potential confounding factors, no significant differences were found in all the measured parameters $(p>0.05)$. Conclusions: We did not find associations between bone health and the dietary intake of three heavy metals in postmenopausal women. Dietary intake of the measured heavy metals were within the recommended values.
\end{abstract}

Keywords: diet records; heavy metals; quantitative bone ultrasound; dual X-ray absorptiometry; tomography

\section{Introduction}

Exposure to heavy metals, such as lead, cadmium, and mercury, occurs through contaminated food sources and water; furthermore, they can be inhaled from cigarette smoke and other sources of air pollution [1]. Cadmium exposure among non-occupationally exposed people occurs primarily via smoking tobacco and secondarily by eating foods containing cadmium [2]. Once inhaled or ingested, cadmium, lead, and mercury are distributed in different tissues and organs [3,4]. Cadmium is inefficiently excreted and accumulates primarily in the liver and kidneys [2]. Tissue stores of cadmium and mercury are slowly excreted from the body via urine and feces at an approximately equal rate, whereas lead is rapidly excreted via urine $[3,5]$.

Cadmium affects the absorption of key divalent cations for bone metabolism such as calcium [1]. There have also been relationships described between several essential elements such as $\mathrm{Ca}, \mathrm{Fe}$ and 
$\mathrm{Zn}$ that affect their absorption, excretion and tissue retention [1]. Cadmium is also able to interfere with the parathyroid hormone stimulation of vitamin D activation in kidney cells, to increase urinary exretion of $\mathrm{Ca}$, reduce its absorption from the intestines, and to interfere with Ca incorporation into bone cells [6]. Dermience et al. [7] recently reviewed and summarized the toxic effects of lead and cadmium on bone metabolism; their study also highlighted the currently unknown effect of mercury on human bone metabolism and the need for further investigation about the possible effects of mercury on bone metabolism. Lead has been related to increased bone turnover and reduced mineralization, a decrease in bone mineral density (BMD) and mass as well as a cause of osteoporosis in the most severe cases [7]. Lead $\left(\mathrm{Pb}^{2+}\right)$ can substitute to $\mathrm{Ca}(2+)$ in hydroxyapatite crystal and additionally lead has a higher affinity for osteocalcin than calcium $[7,8]$. Cadmium has been associated with a decrease in BMD, cadmium interacts with calcium metabolism and causes hypercalciuria, increased risk of fracture, osteomalacia and osteoporosis and chronic cadmium exposure causes Itai-itai disease [7,9], which is associated with weak and brittle bones. There is also evidence that cadmium disturbs calcium metabolism and calciotropic homones; cadmium decreases liver concentration of other elements such as iron, magnesium, and selenium, and increases levels of copper, zinc and manganese [7].

Previous studies have shown that femur T-scores are associated with the accumulation of cadmium, and this association is gender-specific [5,10-12]. Urine cadmium levels have also been associated with osteoporosis $[13,14]$ and dietary intake $[15,16]$. Even low-level cadmium exposure from food has been associated with low BMD and an increased risk of osteoporosis and fractures [17]. Blood levels of lead, mercury and cadmium are negatively associated with BMD, and this association is gender-specific [18].

Few studies have investigated the extent to which dietary heavy metals are associated with low BMD [17].

We aimed to characterize the dietary intake of the heavy metals lead, cadmium and mercury among healthy, non-smoking postmenopausal women (the population stratum with high cadmium retention) [19] in Spain. Furthermore, we sought to establish a putative relationship between bone health and the intake of these heavy metals in similar groups of women.

\section{Materials and Methods}

\subsection{Participants}

Healthy postmenopausal women were recruited from the local area via internet advertising and primary care consults. To be eligible for this study, all women had to be healthy, reside in the community, be of white European origin and have no mental or physical functional impairments.

The University of Extremadura Ethical Advisory Committee approved this study. All participants provided written informed consent in accordance with the 1975 Declaration of Helsinki.

We aimed to have enough power to detect a clinically significant $5.4 \%$ change in lumbar spine BMD [20]. A sample size of at least $n=228$ (two groups of 114) was required [21] to achieve a statistical power of $80 \%$ and $p<0.05$. A total of 281 postmenopausal women were included in this study.

All of the women resided in the urban area of the health district of Caceres, Spain. These women underwent primary or secondary examinations. Most of them were married and had children, and their social status was average. None of the participants had dietary restrictions, neurological impairments, or physical disabilities, and their medical histories showed no presence of low-trauma fractures.

We recorded participants' complete medical histories and physically examined each woman before enrollment in the study. None of the women were taking medications that could interfere with calcium metabolism (e.g., corticoids, oral anticoagulants, antipsychotics, etc.). All of the women led active lives but did not regularly exercise. Alcohol intake was sporadic and did not exceed $100 \mathrm{~mL} /$ day in any case. None of the women smoked. Height was measured using a Harpenden stadiometer with a mandible plane parallel to the floor, and weight was measured using a biomedical precision balance scale. Both measurements were determined when the participants were wearing only light clothing 
and no shoes. Body mass index (BMI) was calculated as the weight in kilograms divided by the square of the height in meters $\left(\mathrm{kg} / \mathrm{m}^{2}\right)$.

\subsection{Bone Measurements}

An ultrasound was performed on the 2nd to the 5th proximal phalanx of the non-dominant hand using a DBM Sonic Bone Profiler (IGEA, Capri, Italy).

The femoral neck and L2-L4 spine BMDs were measured via dual-energy X-ray absorptiometry DXA (Norland XR-800, Norland Inc., Fort Atkinson, WI, USA) and expressed as the quantity of mineral (g) divided by the area scanned $\left(\mathrm{cm}^{2}\right)$.

pQCT measurements were performed on the non-dominant distal forearm using a Stratec XCT-2000 device (Stratec Medizintechnik, Pforzheim, Germany).

\subsection{Assessment of Diet and Covariates}

According to Food and Agriculture Organization/World Health Organization (FAO/WHO) recommendations (WHO, 1985), three basic approaches are employed to assess the intake of food contaminants or other dietary elements: (a) total diet studies (TDSs), (b) duplicate diet studies, and (c) diary studies that combine the data for specific contaminants with individual (or household) consumption records (Perello et al., 2014). Women enrolled in this study completed a 131-item food frequency questionnaire (FFQ). This FFQ was previously validated and involves $24-\mathrm{h}$ recall performed over seven days [22-26]. A food cadmium, lead and mercury database was constructed based on the cadmium, lead and mercury contents previously reported with regard to the Spanish market [27]. Significant differences were not observed in the dietary patterns across geographical areas of Spain; however, the quantities consumed differed greatly [28]. The daily intake of the elements considered for the different food groups was calculated by accounting for food content and consumption. The toxic element concentrations of the different food groups were taken from the literature [28]. Using the FFQ, we also assessed the dietary intake of calcium and vitamin D. Information regarding calcium and vitamin D originated from the Spanish Food Composition database [29].

\subsection{Statistical Analyses}

Medians and the interquartile ranges were used to describe the sample.

Because of the asymmetric distribution of many of the studied variables (i.e., age, Ad-SoS, FN BMD, WT BMD, L2 BMD, L3 BMD, L2-L4 BMD, total area $\mathrm{mm}^{2}$, cortical area $\mathrm{mm}^{2}$, daily Cd intake, vitamin $\mathrm{D}$ intake, Ca intake, Fe intake, $\mathrm{Mg}$, intake and Kcal intake) and the presence of atypical values (i.e., outliers), the non-parametric Wilcoxon test was used to evaluate the differences between groups with regard to the studied variables. To adjust for potential confounds, we used a non-parametric rank analysis of covariance model, where heavy metal intake was considered a factor, and kcal intake was considered a covariate. All statistical tests were conducted in SPSS version 22.0 (IBM Corp., Armonk, NY, USA).

\section{Results}

\subsection{Dietary Heavy Metals Exposure and Major Food Sources in the Whole Sample}

The average estimated dietary cadmium exposure among the 281 women studied was $29.87 \mu \mathrm{g} /$ day (20.55-40.90) and $3.04 \mu \mathrm{g} / \mathrm{kg}$ body weight (b.w.; 2.19-4.41). Dietary lead exposure was $46.25 \mu \mathrm{g} /$ day (38.13-56.71) and $4.88 \mu \mathrm{g} / \mathrm{kg}$ b.w. (4.01-6.09). The estimated dietary mercury exposure was $11.64 \mu \mathrm{g} /$ day (7.68-16.10) and $1.19 \mu \mathrm{g} / \mathrm{kg}$ b.w. (0.82-1.77).

The major sources of dietary cadmium exposure were fish and cereals, which constituted $89 \%$ of the total intake (Figure 1). The major sources of dietary lead were cereals, meat and fruits, together accounting for $80 \%$ of the total intake (Figure 1). Finally, the major sources of dietary mercury were fish and meat, constituting $94 \%$ of the total intake. 

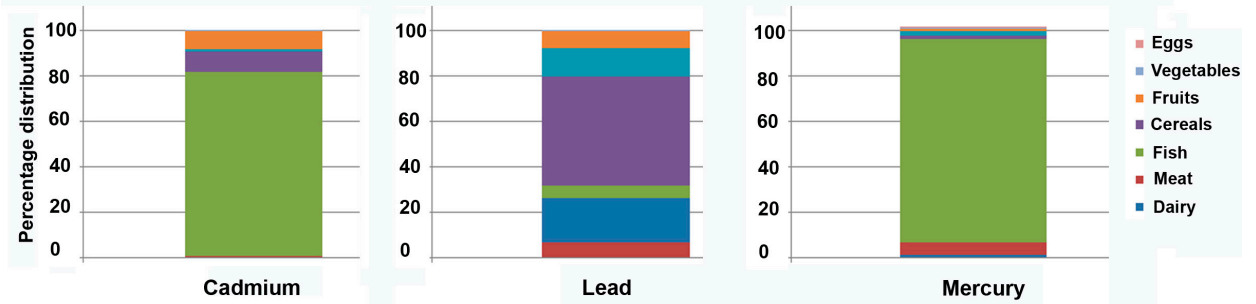

Figure 1. Percentage contribution of various food groups towards the total daily diet.

3.2. Sample Characteristics with Regard to Low and High Heavy Metal Dietary Exposure (Above or Below the Respective Medians)

Table 1 (cadmium), Table 2 (lead) and Table 3 (mercury) show the sample characteristics with regard to low and high heavy metal dietary exposure (above or below the respective medians). Women with high dietary heavy metal exposure reported consuming more vitamin $\mathrm{D}$, calcium, iron and magnesium than those with less dietary heavy metal exposure. After adjusting for calorie consumption, no differences were found with regard to dietary vitamin D consumption in the lead subgroups or dietary calcium consumption in the mercury subgroups (Tables 2 and 3, respectively). The remaining studied were also significant. Dietary exposure to heavy metals was positively associated with dietary calcium $(\mathrm{r}=0.147 ; p=0.014)$, dietary iron $(\mathrm{r}=0.380 ; p<0.001)$, and dietary magnesium $(\mathrm{r}=0.220$; $p<0.001)$ but was not associated with the intake of vitamin $\mathrm{D}(p=0.414)$ after adjusting for calorie intake. Similarly, dietary lead was positively associated with dietary calcium $(\mathrm{r}=0.232 ; p<0.001)$, dietary iron $(\mathrm{r}=0.421 ; p<0.001)$, and dietary magnesium $(\mathrm{r}=0.220 ; p<0.001)$ but not associated with vitamin $\mathrm{D}$ intake $(p=0.878)$. Dietary vitamin $\mathrm{D}$ was also not associated with the dietary mercury $(p=0.422)$, whereas dietary calcium was associated with dietary mercury $(\mathrm{r}=0.133 ; p=0.027)$. Dietary iron $(\mathrm{r}=0.372 ; p<0.001)$ and dietary magnesium $(\mathrm{r}=0.201 ; p<0.001)$ were also associated.

Table 1. Sample characteristics of low and high cadmium dietary exposure (above or below the respective medians).

\begin{tabular}{|c|c|c|c|c|}
\hline & Low $(<29.87$ g/day $)$ & High (>29.87 $\mu \mathrm{g} /$ day) & \multirow{2}{*}{$p$-Value } & \multirow{2}{*}{$p$-Value * } \\
\hline & Median (IQR) & Median (IQR) & & \\
\hline Age at measurement & $57(54-61)$ & $59(55-63)$ & 0.18 & \\
\hline Dietary vitamin D ( $\mu \mathrm{g} /$ day) & $4.08(2.47-7.15)$ & $8.67(4.89-13.33)$ & $<0.001$ & $<0.001$ \\
\hline Dietary calcium (mg/day) & $915(613-1221.5)$ & $1214(883-1528)$ & $<0.001$ & 0.04 \\
\hline Dietary Iron (mg/day) & $12.01(9.5-15.41)$ & $15.91(13.28-21.88)$ & $<0.001$ & $<0.001$ \\
\hline Dietary cadmium/body weigth ( $\mu \mathrm{g} / \mathrm{kg}$ b.w) & $2.18(1.61-2.66)$ & $4.40(3.65-5.85)$ & $<0.001$ & $<0.001$ \\
\hline Dietary cadmium ( $\mu \mathrm{g} /$ day $)$ & $20.55(15.60-25.10)$ & $41.04(34.90-54.55)$ & $<0.001$ & $<0.001$ \\
\hline
\end{tabular}

* After further adjustment by energy intake.

Table 2. Sample characteristics of low and high lead dietary exposure (above or below the respective medians).

\begin{tabular}{|c|c|c|c|c|}
\hline Characteristics & Low $(<46.25 \mu \mathrm{g} /$ day $)$ & High (>46.5 $\mu \mathrm{g} /$ day) & $p$-Value & $p$-Value * \\
\hline Age at measurement & $58(54.5-63)$ & $58(55-62)$ & 0.74 & \\
\hline Dietary vitamin D ( $\mu \mathrm{g} /$ day $)$ & $4.04(2.46-8.5)$ & $7.65(4.53-12.01)$ & $<0.001$ & 0.07 \\
\hline Dietary calcium (mg/day) & 798 (586-1105) & $1293(1005-1589.25)$ & $<0.001$ & $<0.001$ \\
\hline Dietary Iron (mg/day) & $11.35(8.96-14.17)$ & $16.99(13.99-22.47)$ & $<0.001$ & $<0.001$ \\
\hline Dietary lead/body weigth ( $\mu \mathrm{g} / \mathrm{kg}$ b.w) & $4.01(3.34-4.61)$ & $56.77(50.65-67.95)$ & $<0.001$ & $<0.001$ \\
\hline Dietary lead ( $\mu$ g/day) & $38.13(32.96-42.27)$ & $6.14(5.25-7.84)$ & $<0.001$ & $<0.001$ \\
\hline
\end{tabular}

${ }^{*}$ After further adjustment by energy intake. 
Table 3. Sample characteristics of low and high mercury dietary exposure (above or below the respective medians).

\begin{tabular}{|c|c|c|c|c|}
\hline \multirow{2}{*}{ Characteristics } & Low $(<11.65 \mu \mathrm{g} /$ day $)$ & High (>11.65 $\mu \mathrm{g} /$ day) & \multirow{2}{*}{$p$-Value } & \multirow{2}{*}{$p$-Value * } \\
\hline & Median (IQR) & Median (IQR) & & \\
\hline Age at measurement & $57(54-62)$ & $58.5(55-63)$ & 0.28 & \\
\hline Body mass index $\left(\mathrm{kg} / \mathrm{m}^{2}\right)$ & $27.58(24.61-30.41)$ & $27.33(24.45-29.09)$ & 0.25 & \\
\hline Dietary vitamin D ( $\mu \mathrm{g} /$ day $)$ & $3.78(2.26-7,13)$ & $8.67(5.08-13.33)$ & $<0.001$ & $<0.001$ \\
\hline Dietary calcium (mg/day) & $902(618.5-1232.5)$ & $1208(896.5-1528)$ & $<0.001$ & 0.12 \\
\hline Dietary Iron (mg/day) & $11.74(9.47-15.12)$ & $16.26(13.35-22.05)$ & $<0.001$ & $<0.001$ \\
\hline Dietary energy (Kcal/day) & $1981.2(1610.65-2305.1)$ & 2362.15 (1989.42-2712.27) & $<0.001$ & N/A \\
\hline Dietary magnesium (mg/day) & $215.3(173.75-290.4)$ & $322.2(239.3-407.57)$ & $<0.001$ & $<0.001$ \\
\hline Dietary mercury/body weigth ( $\mu \mathrm{g} / \mathrm{kg}$ b.w) & $4.19(3.51-5.01)$ & $53.21(45.10-66.40)$ & $<0.001$ & $<0.001$ \\
\hline Dietary mercury ( $\mu \mathrm{g} /$ day) & $40.05(34.24-46.63)$ & $5.80(4.73-7.36)$ & $<0.001$ & $<0.001$ \\
\hline
\end{tabular}

* After further adjustment by energy intake.

\subsection{Bone Health and Dietary Intake of Heavy Metals}

Table 4 (cadmium), Table 5 (lead) and Table 6 (mercury) show the bone density parameter data. A significant difference was only observed in trabecular density, and this difference remained significant after adjusting for calorie intake in the lead subgroup analysis $(p=0.049)$. Women who consumed more lead presented higher trabecular densities than those with less lead intake. A significant difference was also found in L2 BMD, but this difference remained non-significant after adjustment $(p=0.056)$. No other differences were found in the subgroup analysis.

Table 4. Quantitative bone ultrasound, bone mineral density and volumetric bone mineral density for low and high cadmium dietary exposure (above or below the respective medians).

\begin{tabular}{|c|c|c|c|}
\hline \multirow{2}{*}{ Measurement } & Low $(<29.87 \mu g /$ day $)$ & High (>29.87 $\mu \mathrm{g} /$ day) & \multirow{2}{*}{$p$-Value } \\
\hline & Median (IQR) & Median (IQR) & \\
\hline \multicolumn{4}{|l|}{ Quantitative bone ultrasound } \\
\hline Ad-SoS (m/s) & 2042 (1995.5-2088) & $2040(2000-2093.25)$ & 0.986 \\
\hline \multicolumn{4}{|l|}{ Bone mineral density $\left(\mathrm{gr} / \mathrm{cm}^{2}\right)$} \\
\hline BMD Femoral neck & $0.829(0.769-0.914)$ & $0.839(0.772-0.901)$ & 0.968 \\
\hline BMD Femoral trochanter & $0.684(0.609-0.733)$ & $0.667(0.619-0.726)$ & 0.629 \\
\hline BMD Ward's triangle & $0.599(0.542-0.684)$ & $0.621(0.545-0.673)$ & 0.657 \\
\hline BMD L2 & 1.005 (0.937-1.097) & $1.000(0.945-1.065)$ & 0.322 \\
\hline BMD L3 & $1.044(0.966-1.125)$ & $1.033(0.975-1.091)$ & 0.282 \\
\hline BMD L4 & $1.019(0.951-1.104)$ & $0.991(0.928-1.094)$ & 0.098 \\
\hline BMD lumbar spine & $1.026(0.960-1.098)$ & $1.004(0.950-1.077)$ & 0.172 \\
\hline \multicolumn{4}{|l|}{ Volumetric BMD (mg/cm $\left.{ }^{3}\right)$} \\
\hline Total density & $337.5(306.95-369.9)$ & $337.2(300.775-367.55)$ & 0.702 \\
\hline Trabecular density & $181.4(162.45-207.2)$ & $173.55(149.65-203.325)$ & 0.339 \\
\hline Cortical density & $458.1(413.4-508.5)$ & $468.95(418-513.725)$ & 0.085 \\
\hline \multicolumn{4}{|l|}{ Bone morphometry $\left(\mathrm{mm}^{2}\right)$} \\
\hline Total area & $298(273.75-323.35)$ & $292.45(265.55-317.1)$ & 0.337 \\
\hline Trabecular area & $134(123.05-145.35)$ & $131.6(119.7-142.4)$ & 0.608 \\
\hline Cortical area & $163.8(150.45-177.42)$ & $161(146.3-174.625)$ & 0.351 \\
\hline
\end{tabular}


Table 5. Quantitative bone ultrasound, bone mineral density and volumetric bone mineral density for low and high lead dietary exposure (above or below the respective medians).

\begin{tabular}{|c|c|c|c|c|}
\hline \multirow{2}{*}{ Measurement } & Low $(<46.25 \mu \mathrm{g} / \mathrm{day})$ & High (>46.25 $\mu \mathrm{g} /$ day) & \multirow{2}{*}{$p$-Value } & \multirow{2}{*}{$p$-Value * } \\
\hline & Mean (IQR) & Mean (IQR) & & \\
\hline \multicolumn{5}{|l|}{ Quantitative bone ultrasound } \\
\hline Ad-SoS (m/s) & 2037 (1994-2085.5) & $2042(2007.25-2096)$ & 0.13 & \\
\hline \multicolumn{5}{|l|}{ Bone mineral density $\left(\mathrm{gr} / \mathrm{cm}^{2}\right)$} \\
\hline BMD Femoral neck & $0.829(0.766-0.913)$ & $0.835(0.7745-0.898)$ & 0.943 & \\
\hline BMD Femoral trochanter & $0.684(0.608-0.737)$ & $0.669(0.611-0.717)$ & 0.575 & \\
\hline BMD Ward's triangle & $0.609(0.542-0.684)$ & $0.616(0.544-0.679)$ & 0.934 & \\
\hline BMD L2 & $1.032(0.952-1.097)$ & $0.990(0.936-1.053)$ & 0.008 & 0.056 \\
\hline BMD L3 & $1.05(0.975-1.125)$ & $1.03(0.962-1.089)$ & 0.087 & \\
\hline BMD L4 & $1.015(0.943-1.104)$ & $0.995(0.935-1.086)$ & 0.217 & \\
\hline BMD lumbar spine & $1.027(0.964-1.099)$ & $0.999(0.949-1.07)$ & 0.052 & \\
\hline \multicolumn{5}{|l|}{ Volumetric BMD $\left(\mathrm{mg} / \mathrm{cm}^{3}\right)$} \\
\hline Total density & $340.2(307.2-376.9)$ & $334.8(302.775-362.175)$ & 0.109 & \\
\hline Trabecular density & $291.4(266.8-318.7)$ & $299.7(273.475-324.325)$ & 0.001 & 0.049 \\
\hline Cortical density & $186.8(163.7-210.85)$ & $171.15(149.65-195.3)$ & 0.746 & \\
\hline \multicolumn{5}{|l|}{ Bone morphometry $\left(\mathrm{mm}^{2}\right)$} \\
\hline Total area & $130.9(120.25-142.95)$ & $135.25(123.6-145.9)$ & 0.333 & \\
\hline Trabecular area & $460.1(414.35-516.1)$ & $465.6(417.6-503.875)$ & 0.269 & \\
\hline Cortical area & $160.5(146.975-173.625)$ & $165(150.975-178.6)$ & 0.242 & \\
\hline
\end{tabular}

Table 6. Quantitative bone ultrasound, bone mineral density and volumetric bone mineral density for low and high mercury dietary exposure (above or below the respective medians).

\begin{tabular}{|c|c|c|c|}
\hline \multirow{2}{*}{ Measurement } & Low $(<11.65 \mu \mathrm{g} /$ day $)$ & High (>11.65 $\mu \mathrm{g} /$ day) & \multirow{2}{*}{$p$-Value } \\
\hline & Mean (IQR) & Mean (IQR) & \\
\hline \multicolumn{4}{|l|}{ Quantitative bone ultrasound } \\
\hline Ad-SoS (m/s) & 2042 (1997-2088.5) & 2040 (1999.25-2089.75) & 0.956 \\
\hline \multicolumn{4}{|l|}{ Bone mineral density $\left(\mathrm{gr} / \mathrm{cm}^{2}\right)$} \\
\hline BMD Femoral neck & $0.829(0.769-0.913)$ & $0.839(0.772-0.901)$ & 0.984 \\
\hline BMD Femoral trochanter & $0.684(0.61-0.735)$ & $0.667(0.612-0.723)$ & 0.554 \\
\hline BMD Ward's triangle & $0.600(0.543-0.690)$ & $0.62(0.543-0.670)$ & 0.868 \\
\hline BMD L2 & $1.003(0.951-1.097)$ & $1.005(0.937-1.067)$ & 0.267 \\
\hline BMD L3 & $1.043(0.972-1.118)$ & $1.033(0.974-1.093)$ & 0.341 \\
\hline BMD L4 & $1.015(0.951-1.104)$ & $0.996(0.928-1.094)$ & 0.125 \\
\hline BMD lumbar spine & $1.026(0.961-1.096)$ & $1.006(0.948-1.084)$ & 0.183 \\
\hline \multicolumn{4}{|l|}{ Volumetric BMD $\left(\mathrm{mg} / \mathrm{cm}^{3}\right)$} \\
\hline Total density & $338.3(306.95-369.9)$ & $336.8(300.775-367.55)$ & 0.655 \\
\hline Trabecular density & $294.1(269.1-323.35)$ & $294.5(267.475-317.4)$ & 0.084 \\
\hline Cortical density & $182.2(161.5-207.45)$ & 173.55 (152.475-200.725) & 0.69 \\
\hline \multicolumn{4}{|l|}{ Bone morphometry $\left(\mathrm{mm}^{2}\right)$} \\
\hline Total area & $132.3(121.85-144.8)$ & $132.8(120.4-143.225)$ & 0.859 \\
\hline Trabecular area & $458.2(414.1-508.5)$ & $467.9(417.6-513.725)$ & 0.99 \\
\hline Cortical area & $161.7(149.175-177.1)$ & $162.25(147.3-174.7)$ & 0.96 \\
\hline
\end{tabular}

\subsection{Risk of Low Bone Mineral Density and Dietary Intake of Heavy Metals}

We explored the risk of low BMD (i.e., a T-score < -1) at either the hip (femoral neck) or the lumbar spine for dietary cadmium, lead and mercury. We observed a non-significant OR of 0.840 (95\% CIs $=0.363-1.944 ; p=0.68)$ for the hip and a non-significant OR of 1.386 (95\% CIs = 0.766-2.510; $p=0.28$ ) for the lumbar spine among the cadmium groups. Similarly, a non-significant OR of $1.008(95 \%$ CIs $=0.437-2.327 ; p=0.98)$ was observed for the hip, and a non-significant OR of 
$1.520(95 \%$ CIs $=0.838-2.759 ; p=0.15)$ was observed for the lumbar spine among the lead subgroup. A non-significant OR of $0.84(95 \%$ CIs $=0.363-1.944 ; p=0.68)$ was observed for the hip, and a non-significant OR of 1.668 (95\% CIs $=0.916-3.038 ; p=0.09)$ was observed for the lumbar spine among the dietary mercury subgroup. We also explored the risk of low BMD after adjusting for the dietary intake of calcium, magnesium, iron, vitamin $\mathrm{D}$ and calories via a logistic regression. A non-significant OR was observed for the hip (OR $=1.461 ; 95 \% \mathrm{CIs}=0.571-3.741 ; p=0.429)$ and lumbar spine (OR $=0.767 ; 95 \% \mathrm{CIs}=0.396-1.489 ; p=0.432)$ among the cadmium subgroup. Furthermore, a non-significant OR was observed for the lumbar spine (OR $=0.830 ; 95 \%$ CIs $=0.399-1.729 ; p=0.031)$ and the hip (OR $=1.221 ; 95 \%$ CIs $=0.429-3.469 ; p=0.709$ ) among the lead subgroup. Finally, no significant differences were observed in the mercury subgroup for the hip (OR $=1.458 ; 95 \%$ CIs $=0.557-3.818 ; p=0.443)$ or lumbar spine $(\mathrm{OR}=0.652 ; 95 \% \mathrm{CIs}=0.344-1.237 ; p=0.191)$.

\subsection{Combined Intake of Heavy Metals and Bone Health}

In the final analysis, we assessed the combined effect of a high dietary intake of the studied heavy metals. These data are shown in Table 7. No significant differences were found between the groups for age ( $p=0.593)$ or BMI (0.052). Significant differences were found regarding L2 BMD $(p=0.013)$ and the lumbar spine $(p=0.023)$. In both cases, BMD was slightly higher in women with a higher intake of heavy metals. The differences regarding the lumbar spine remained after adjusting for calorie intake $(p=0.037)$. The differences observed in the trabecular area $(p=0.004)$ remained non-significant after adjusting for calorie intake $(p=0.107)$.

Table 7. Combined association of a high dietary intake of the studied heavy metals over the quantitative bone ultrasound, bone mineral density and volumetric bone mineral density.

\begin{tabular}{|c|c|c|c|}
\hline & $\begin{array}{l}\text { Combined High Dietary } \\
\text { Intake of Heavy Metals }\end{array}$ & $\begin{array}{l}\text { Combined Low Intake } \\
\text { of Heavy Metals }\end{array}$ & $p$-Value \\
\hline & Median (IQR) & Median (IQR) & \\
\hline \multicolumn{4}{|l|}{ Quantitative bone ultrasound } \\
\hline Ad-SoS (m/s) & 2038.5 (1995.25-2086) & 2041 (2006.5-2095) & 0.424 \\
\hline \multicolumn{4}{|l|}{ Bone mineral density $\left(\mathrm{gr} / \mathrm{cm}^{2}\right)$} \\
\hline BMD Femoral neck & $0.829(0.770-0.914)$ & $0.842(0.782-0.906)$ & 0.766 \\
\hline BMD Femoral trochanter & $0.692(0.609-0.746)$ & $0.676(0.622-0.730)$ & 0.515 \\
\hline BMD Ward's triangle & $0.602(0.543-0.687)$ & $0.620(0.547-0.680)$ & 0.836 \\
\hline BMD L2 & $1.032(0.954-1.103)$ & $0.995(0.941-1.053)$ & 0.013 \\
\hline BMD L3 & $1.059(0.977-1.14)$ & $1.034(0.975-1.091)$ & 0.051 \\
\hline BMD L4 & $1.026(0.954-1.124)$ & $0.994(0.934-1.097)$ & 0.071 \\
\hline BMD lumbar spine & $1.042(0.965-1.106)$ & $1.004(0.947-1.069)$ & $0.023 *$ \\
\hline \multicolumn{4}{|l|}{ Volumetric BMD $\left(\mathrm{mg} / \mathrm{cm}^{3}\right)$} \\
\hline Total density & $339.25(310.525-375.7)$ & $335.2(301.9-366.1)$ & 0.2 \\
\hline Trabecular density & $295.7(271.9-321.95)$ & $301(273.65-324.25)$ & 0.004 \\
\hline Cortical density & $185.05(162.275-207.2)$ & $168.3(148.55-193.25)$ & 0.922 \\
\hline \multicolumn{4}{|l|}{ Bone morphometry $\left(\mathrm{mm}^{2}\right)$} \\
\hline Total area & $133(122.2-144.625)$ & $135.4(123.6-145.9)$ & 0.722 \\
\hline Trabecular area & $458.15(417.575-525.6)$ & $469.6(418.55-515.2)$ & 0.662 \\
\hline Cortical area & $161.9(149.7-176.8)$ & $165.7(151.25-178.6)$ & 0.619 \\
\hline
\end{tabular}

\section{Discussion}

Our sample of postmenopausal women had a dietary cadmium intake that was notably lower than the provisional tolerable weekly intake (PTWI) established by the Joint FAO/WHO Expert Committee on Food Additives (JECFA; $7 \mu \mathrm{g} / \mathrm{kg}$ b.w./week) [30]. In 2009, however, the European Food Safety Authority (EFSA) [31,32] reevaluated data on dietary cadmium intake and set a new PTWI of 
$2.5 \mu \mathrm{g} / \mathrm{kg}$ b.w. (0.357 $\mu \mathrm{g} / \mathrm{kg}$ b.w./day) [33]. Approximately $66 \%$ of the sample exceeded the threshold for this element.

JECFA has established a PTWI for lead of $25 \mu \mathrm{g} / \mathrm{kg}$ b.w.; however, the EFSA [34] concluded that the former PTWI (given as $\mu \mathrm{g} / \mathrm{kg}$ b.w.) was not appropriate because no evidence of a critical threshold for lead-induced effects exists. In 2011, the JECFA concluded that because of prior analyses, a critical threshold would be considered health protective [33]. Nevertheless, all of the women had values well below the PTWI.

With respect to mercury, the EFSA recommends a maximum intake of $4 \mu \mathrm{g} / \mathrm{kg}$ b.w. $/$ week [33], and only $0.7 \%$ of the sample exceeded this threshold. Previous studies $[27,35]$ in different areas of Spain studied the intake of heavy metals and other potentially toxic materials. The results obtained regarding the average dietary intake of lead ranged from $4 \mu \mathrm{g} / \mathrm{kg}$ b.w. $/$ week to $56 \mu \mathrm{g} / \mathrm{kg}$ b.w. $/$ week among the four areas studied. These results are similar to the dietary intakes assessed in our area $(4.8 \mu \mathrm{g} / \mathrm{kg}$ b.w./week).

In 2014, the temporal trends of the dietary intakes of cadmium, lead and mercury $(2000,2005$, 2008 and 2012) were estimated for Catalonia, Spain [33]. The dietary intakes for cadmium, mercury, and lead in this region were $0.87 \mu \mathrm{g} / \mathrm{kg}$ b.w. $/$ week, $1.1 \mu \mathrm{g} / \mathrm{kg}$ b.w. $/$ week and $0.84 \mu \mathrm{g} / \mathrm{kg}$ b.w. $/$ week, respectively; these figures are below the values observed in our sample. The data from our study confirm previous studies in different areas of Spain showing that the dietary intakes of heavy metals in the Spanish diet are generally within the recommended limits [36-43]. Moreiras and Cuadrado [28] examined the estimated intake of heavy metals in the diets of people from our specific area of Spain in 1992 and indicated that Extremadura showed the theoretically lowest intake of cadmium but the highest intake of mercury in all of Spain. It is possible that the dietary habits of our area have changed since then, thereby changing the trend in the dietary intake of the studied heavy metals.

According to Perelló and colleagues [33], the major dietary sources of cadmium are cereals and fish; these conclusions corroborate our results. Similar results were found for the intake of mercury: fish was the major dietary contributor. Cereals made the greatest contribution to total dietary lead intake in three of the four areas studied; this result supports our observation about the contribution of cereals to the dietary intake of lead in the current sample. A previous study also showed that cereals are a major source of dietary lead and cadmium in Spain [44].

An association exists between dietary cadmium exposure and higher rates of bone fracture (including hip fracture) independent of tobacco smoking in men [45]. Similarly, even low-level exposure to dietary cadmium has been associated with bone fragility among postmenopausal women [17]. Recently, positive associations with osteoporosis-related incident fractures were described in a cohort of elderly Swedish men, and these associations were also described in men who had never smoked but who were exposed primarily through their diets [46]. These results show that older men with relatively low dietary cadmium exposure are also at an increased risk of low BMD and fracture associated with cadmium.

Although high cadmium exposure causes bone damage, the association between low-level cadmium exposure (i.e., dietary exposure) and bone health must be clarified, especially in women [47]. Little evidence exists on the associations between BMD status and cadmium, lead or mercury intake among osteopenic or osteoporotic Korean adults [48]. However, the negative effects of low-level cadmium exposure on bone, possibly exerted via increased bone resorption, seem to intensify after menopause [47]. We did not observe any association between BMD and dietary cadmium intake in our cohort of Spanish women. Recent research has focused on the putative roles that cadmium plays in volumetric BMD and bone morphometry. In vivo studies of Sprague-Dawley male rats have shown that cadmium exposure can induce low vBMD [49] by decreasing the trabecular number, thereby reducing the quantity of mineralized bone tissue.

Similarly, conflicting evidence suggests that bone lead or blood lead reduces areal BMD. Recent data have shown that bone lead accumulated from exposure over time can detrimentally affect bone by reducing cortical thickness and integral volumetric bone density [50] in postmenopausal women. 
We observed a non-significant difference in the trabecular density between the groups of women with either high or low dietary intakes of lead; the trabecular density of the higher dietary cadmium intake group was greater. We believe that this result deserves additional study because it might support the hypothesis that lead affects volumetric BMD.

The strengths of our study include its use of a heavy metals database based on concentrations in foods sold on the Spanish market as well as the assessment of BMD via DXA (the reference standard for BMD measurements), volumetric BMD and bone morphometry via pQCT and bone quality via QUS.

We recognize that our study has several limitations. First, its cross-sectional design does not allow us to establish causal relationships. Second, although we adjusted for calorie intake and no differences were observed in the major determinants of bone density between the studied groups (age, BMI, calcium intake, vitamin D intake, or smoking status), we cannot completely exclude the possibility that our findings are biased by unmeasured or residual confounds. Additionally, we aimed to have enough power to detect a least significant change in spine BMD of $5.4 \%$ that was established for intragroup comparisons and this could be conservative. Therefore, our study might have a moderate risk of finding no difference when in fact a difference might exist below the indicated threshold. Finally, dietary estimation of cadmium exposure should be used with caution in our study because of the lack of association between estimated dietary cadmium and measured urinary cadmium exposure.

\section{Conclusions}

The current study provides the first observational data regarding volumetric BMD, bone morphometry, QUS and the dietary intakes of cadmium, lead and mercury among Spanish women. With the use of newer imaging techniques, such as $\mathrm{PQCT}$, which provide more information about bone quality than standard methods such as DXA, we did not find associations between bone health and the dietary intakes of three heavy metals.

Acknowledgments: This work was supported in part by the Government of Extremadura through project GR15144. The founding sponsors had no role in the design of the study; in the collection, analyses, or interpretation of data; in the writing of the manuscript, and in the decision to publish the results.

Author Contributions: Jose M. Moran, Luis M. Puerto-Parejo, Ignacio Aliaga contributed to the design of the study. Luis M. Puerto-Parejo, Ignacio Aliaga, María L. Canal-Macias, Raul Roncero-Martín, Olga Leal-Hernández and Sergio Rico-Martín contributed to acquisition and processing of the data. Luis M. Puerto-Parejo, Ignacio Aliaga and Jose M. Moran analyzed the data. Jose M. Moran wrote the first draft of the manuscript. All authors have read and commented on the manuscript and approved the final version.

Conflicts of Interest: The authors declare no conflict of interest.

\section{References}

1. Madeddu, R.; Solinas, G.; Forte, G.; Bocca, B.; Asara, Y.; Tolu, P.; Delogu, L.G.; Muresu, E.; Montella, A.; Castiglia, P. Diet and Nutrients are Contributing Factors that Influence Blood Cadmium Levels. Nutr. Res. 2011, 31, 691-697. [CrossRef] [PubMed]

2. Jarup, L.; Akesson, A. Current Status of Cadmium as an Environmental Health Problem. Toxicol. Appl. Pharmacol. 2009, 238, 201-208. [CrossRef] [PubMed]

3. Boening, D.W. Ecological Effects, Transport, and Fate of Mercury: A General Review. Chemosphere 2000, 40, 1335-1351. [CrossRef]

4. Swiergosz-Kowalewska, R. Cadmium Distribution and Toxicity in Tissues of Small Rodents. Microsc. Res. Tech. 2001, 55, 208-222. [CrossRef] [PubMed]

5. Aaseth, J.; Boivin, G.; Andersen, O. Osteoporosis and Trace Elements-An Overview. J. Trace Elem. Med. Biol. 2012, 26, 149-152. [CrossRef] [PubMed]

6. Kazantzis, G. Cadmium, Osteoporosis and Calcium Metabolism. Biometals 2004, 17, 493-498. [CrossRef] [PubMed]

7. Dermience, M.; Lognay, G.; Mathieu, F.; Goyens, P. Effects of Thirty Elements on Bone Metabolism. J. Trace Elem. Med. Biol. 2015, 32, 86-106. [CrossRef] [PubMed] 
8. Dowd, T.L.; Rosen, J.F.; Mints, L.; Gundberg, C.M. The Effect of $\mathrm{Pb}^{2+}$ on the Structure and Hydroxyapatite Binding Properties of Osteocalcin. Biochim. Biophys. Acta-Mol. Basis Dis. 2001, 1535, 153-163. [CrossRef]

9. Cai, Y.; Aoshima, K.; Katoh, T.; Teranishi, H.; Kasuya, M. Renal Tubular Dysfunction in Male Inhabitants of a Cadmium-Polluted Area in Toyama, Japan-An Eleven-Year Follow-up Study. J. Epidemiol. 2001, 11, 180-189. [CrossRef] [PubMed]

10. Akesson, A.; Berglund, M.; Schutz, A.; Bjellerup, P.; Bremme, K.; Vahter, M. Cadmium Exposure in Pregnancy and Lactation in Relation to Iron Status. Am. J. Public Health 2002, 92, 284-287. [CrossRef] [PubMed]

11. Meltzer, H.M.; Brantsaeter, A.L.; Borch-Iohnsen, B.; Ellingsen, D.G.; Alexander, J.; Thomassen, Y.; Stigum, H.; Ydersbond, T.A. Low Iron Stores are Related to Higher Blood Concentrations of Manganese, Cobalt and Cadmium in Non-Smoking, Norwegian Women in the HUNT 2 Study. Environ. Res. 2010, 110, 497-504. [CrossRef] [PubMed]

12. Qin, Y.Y.; Leung, C.K.M.; Leung, A.O.W.; Wu, S.C.; Zheng, J.S.; Wong, M.H. Persistent Organic Pollutants and Heavy Metals in Adipose Tissues of Patients with Uterine Leiomyomas and the Association of these Pollutants with Seafood Diet, BMI, and Age. Environ. Sci. Pollut. Res. 2010, 17, 229-240. [CrossRef]

13. Jarup, L.; Alfven, T. Low Level Cadmium Exposure, Renal and Bone Effects-The OSCAR Study. Biometals 2004, 17, 505-509. [CrossRef] [PubMed]

14. Jarup, L.; Alfven, T.; Persson, B.; Toss, G.; Elinder, C.G. Cadmium may be a Risk Factor for Osteoporosis. Occup. Environ. Med. 1998, 55, 435-439. [CrossRef] [PubMed]

15. Gallagher, C.M.; Kovach, J.S.; Meliker, J.R. Urinary Cadmium and Osteoporosis in U.S. Women $>$ Or $=50$ Years of Age: NHANES 1988-1994 and 1999-2004. Environ. Health Perspect. 2008, 116, 1338-1343. [CrossRef] [PubMed]

16. Songprasert, N.; Sukaew, T.; Kusreesakul, K.; Swaddiwudhipong, W.; Padungtod, C.; Bundhamcharoen, K. Additional Burden of Diseases Associated with Cadmium Exposure: A Case Study of Cadmium Contaminated Rice Fields in Mae Sot District, Tak Province, Thailand. Int. J. Environ. Res. Public. Health 2015, 12, 9199-9217. [CrossRef] [PubMed]

17. Engstrom, A.; Michaelsson, K.; Vahter, M.; Julin, B.; Wolk, A.; Akesson, A. Associations between Dietary Cadmium Exposure and Bone Mineral Density and Risk of Osteoporosis and Fractures among Women. Bone 2012, 50, 1372-1378. [CrossRef] [PubMed]

18. Lee, K.M.; Kwon, S.S.; Chung, C.Y.; Lee, S.Y.; Kim, T.G.; Choi, Y.; Park, M.S. Gender- and Body-Site-Specific Factors Associated with Bone Mineral Density in a Non-Institutionalized Korean Population Aged $\geq 50$ Years. J. Bone Miner. MeTable 2015, 33, 401-409. [CrossRef] [PubMed]

19. Rignell-Hydbom, A.; Skerfving, S.; Lundh, T.; Lindh, C.H.; Elmståhl, S.; Bjellerup, P.; Jünsson, B.A.G.; Strümberg, U.; Åkesson, A. Exposure to Cadmium and Persistent Organochlorine Pollutants and its Association with Bone Mineral Density and Markers of Bone Metabolism on Postmenopausal Women. Environ. Res. 2009, 109, 991-996. [CrossRef] [PubMed]

20. Lodder, M.; Lems, W.; Ader, H.; Marthinsen, A.; van Coeverden, S.; Lips, P.; Netelenbos, J.; Dijkmans, B.; Roos, J. Reproducibility of Bone Mineral Density Measurement in Daily Practice. Ann. Rheum. Dis. 2004, 63, 285-289. [CrossRef] [PubMed]

21. Rosner, B. Fundamentals of Biostatistics, 7th ed.; Brooks/Cole, Cengage Learning: Pacific Grove, CA, USA, 2011.

22. Calderon-Garcia, J.F.; Moran, J.M.; Roncero-Martin, R.; Rey-Sanchez, P.; Rodriguez-Velasco, F.J.; Pedrera-Zamorano, J.D. Dietary Habits, Nutrients and Bone Mass in Spanish Premenopausal Women: The Contribution of Fish to Better Bone Health. Nutrients 2012, 5, 10-22. [CrossRef] [PubMed]

23. Lavado-Garcia, J.M.; Calderon-Garcia, J.F.; Moran, J.M.; Canal-Macias, M.L.; Rodriguez-Dominguez, T.; Pedrera-Zamorano, J.D. Bone Mass of Spanish School Children: Impact of Anthropometric, Dietary and Body Composition Factors. J. Bone Miner. 2012, 30, 193-201. [CrossRef] [PubMed]

24. Moran, J.M.; Lopez-Arza, L.G.; Lavado-Garcia, J.M.; Pedrera-Canal, M.; Rey-Sanchez, P.; Rodriguez-Velasco, F.J.; Fernandez, P.; Pedrera-Zamorano, J.D. Hormonal Relationships to Bone Mass in Elderly Spanish Men as Influenced by Dietary Calcium and Vitamin D. Nutrients 2013, 5, 4924-4937. [CrossRef] [PubMed]

25. Pedrera-Zamorano, J.D.; Lavado-Garcia, J.M.; Roncero-Martin, R.; Calderon-Garcia, J.F.; Rodriguez-Dominguez, T.; Canal-Macias, M.L. Effect of Beer Drinking on Ultrasound Bone Mass in Women. Nutrition 2009, 25, 1057-1063. [CrossRef] [PubMed] 
26. Pedrera-Zamorano, J.D.; Calderon-Garcia, J.F.; Roncero-Martin, R.; Manas-Nunez, P.; Moran, J.M.; Lavado-Garcia, J.M. The Protective Effect of Calcium on Bone Mass in Postmenopausal Women with High Selenium Intake. J. Nutr. Health Aging 2012, 16, 743-748. [CrossRef] [PubMed]

27. Cuadrado, C.; Kumpulainen, J.; Moreiras, O. Lead, Cadmium and Mercury Contents in Average Spanish Market Basket Diets from Galicia, Valencia, Andalucia and Madrid. Food Addit. Contam. 1995, 12, 107-118. [CrossRef] [PubMed]

28. Moreiras, O.; Cuadrado, C. Theoretical Study of the Intake of Trace Elements (Nutrients and Contaminants) Via Total Diet in some Geographical Areas of Spain. Biol. Trace Elem. Res. 1992, 32, 93-103. [CrossRef] [PubMed]

29. Moreiras, O. Tablas de Composición de Alimentos: Guía de Prácticas, 16 a , amp y rev ed.; Pirámide: Madrid, Spain, 2013; p. 455.

30. World Health Organization. Evaluation of Certain Food Additives and Contaminants; Technical Report Series 960; World Health Organization: Geneva, Switzerland, 2003.

31. European Food Safety Authority. Cadmium Dietary Exposure in the European Population. EFSA J. 2012. [CrossRef]

32. Panel, E.C. Scientific Opinion on Cadmium in Food. EFSA J. 2009, 7, 980.

33. Perello, G.; Llobet, J.M.; Gomez-Catalan, J.; Castell, V.; Centrich, F.; Nadal, M.; Domingo, J.L. Human Health Risks Derived from Dietary Exposure to Toxic Metals in Catalonia, Spain: Temporal Trend. Biol. Trace Elem. Res. 2014, 162, 26-37. [CrossRef] [PubMed]

34. Scientific Opinion on Lead in Food. Available online: http://www.efsa.europa.eu/en/efsajournal/pub/1570 (accessed on 21 May 2017).

35. Cuadrado, C.; Kumpulainen, J.; Moreiras, O. Contaminants and Nutrients in Total Diets in Spain. Eur. J. Clin. Nutr. 1995, 49, 767-778. [PubMed]

36. Bocio, A.; Nadal, M.; Domingo, J. Human Exposure to Metals through the Diet in Tarragona, Spain-Temporal Trend. Biol. Trace Elem. Res. 2005, 104, 193-201. [CrossRef]

37. Lopezartiguez, M.; Soria, M.; Camean, A.; Repetto, M. Cadmium in the Diet of the Local-Population of Seville (Spain). Bull. Environ. Contam. Toxicol. 1993, 50, 417-424.

38. Marti-Cid, R.; Llobet, J.M.; Castell, V.; Domingo, J.L. Dietary Intake of Arsenic, Cadmium, Mercury, and Lead by the Population of Catalonia, Spain. Biol. Trace Elem. Res. 2008, 125, 120-132. [CrossRef] [PubMed]

39. Martorell, I.; Perello, G.; Marti-Cid, R.; Llobet, J.M.; Castell, V.; Domingo, J.L. Human Exposure to Arsenic, Cadmium, Mercury, and Lead from Foods in Catalonia, Spain: Temporal Trend. Biol. Trace Elem. Res. 2011, 142, 309-322. [CrossRef] [PubMed]

40. Rubio, C.; Hardisson, A.; Reguera, J.; Revert, C.; Lafuente, M.; Gonzalez-Iglesias, T. Cadmium Dietary Intake in the Canary Islands, Spain. Environ. Res. 2006, 100, 123-129. [CrossRef] [PubMed]

41. Rubio, C.; Gutierrez, A.; Burgos, A.; Hardisson, A. Total Dietary Intake of Mercury in the Canary Islands, Spain. Food Addit. Contam. Part A Chem. 2008, 25, 946-952. [CrossRef] [PubMed]

42. Urieta, I.; Jalon, M.; Eguilero, I. Food Surveillance in the Basque Country (Spain). II. Estimation of the Dietary Intake of Organochlorine Pesticides, Heavy Metals, Arsenic, Aflatoxin M1, Iron and Zinc through the Total Diet Study, 1990/1991. Food Addit. Contam. 1996, 13, 29-52. [CrossRef] [PubMed]

43. Schuhmacher, M.; Bosque, M.A.; Domingo, J.L.; Corbella, J. Dietary-Intake of Lead and Cadmium from Foods in Tarragona Province, Spain. Bull. Environ. Contam. Toxicol. 1991, 46, 320-328. [CrossRef] [PubMed]

44. Cuadrado, C.; Kumpulainen, J.; Carbajal, A.; Moreiras, O. Cereals Contribution to the Total Dietary Intake of Heavy Metals in Madrid, Spain. J. Food Compos. Anal. 2000, 13, 495-503. [CrossRef]

45. Thomas, L.D.; Michaelsson, K.; Julin, B.; Wolk, A.; Akesson, A. Dietary Cadmium Exposure and Fracture Incidence among Men: A Population-Based Prospective Cohort Study. J. Bone Miner. Res. 2011, 26, 1601-1608. [CrossRef] [PubMed]

46. Wallin, M.; Barregard, L.; Sallsten, G.; Lundh, T.; Karlsson, M.K.; Lorentzon, M.; Ohlsson, C.; Mellstrom, D. Low-Level Cadmium Exposure is Associated with Decreased Bone Mineral Density and Increased Risk of Incident Fractures in Elderly Men: The MrOS Sweden Study. J. Bone Miner. Res. 2016, 31, 732-741. [CrossRef] [PubMed]

47. Akesson, A.; Bjellerup, P.; Lundh, T.; Lidfeldt, J.; Nerbrand, C.; Samsioe, G.; Skerfving, S.; Vahter, M. Cadmium-Induced Effects on Bone in a Population-Based Study of Women. Environ. Health Perspect. 2006, 114, 830-834. [CrossRef] [PubMed] 
48. Kang, M.H.; Park, S.M.; Oh, D.N.; Kim, M.H.; Choi, M.K. Dietary Nutrient and Food Intake and their Relations with Serum Heavy Metals in Osteopenic and Osteoporotic Patients. Clin. Nutr. Res. 2013, 2, $26-33$. [CrossRef] [PubMed]

49. Chen, X.; Zhu, G.; Jin, T.; Qin, B.; Zhou, W.; Gu, S. Cadmium is More Toxic on Volume Bone Mineral Density than Tissue Bone Mineral Density. Biol. Trace Elem. Res. 2011, 144, 380-387. [CrossRef] [PubMed]

50. Wong, A.K.; Beattie, K.A.; Bhargava, A.; Cheung, M.; Webber, C.E.; Chettle, D.R.; Papaioannou, A.; Adachi, J.D.; Canadian Multicentre Osteoporosis Study (CaMos) Research Group. Bone Lead (Pb) Content at the Tibia is Associated with Thinner Distal Tibia Cortices and Lower Volumetric Bone Density in Postmenopausal Women. Bone 2015, 79, 58-64. [CrossRef] [PubMed]

C 2017 by the authors. Licensee MDPI, Basel, Switzerland. This article is an open access article distributed under the terms and conditions of the Creative Commons Attribution (CC BY) license (http://creativecommons.org/licenses/by/4.0/). 